\title{
A new world natural vegetation map for global change studies
}

\author{
DAVID M. LAPOLA ${ }^{1}$, MARCOS D. OYAMA ${ }^{2}$, CARLOS A. NOBRE ${ }^{1}$ and GILVAN SAMPAIO ${ }^{1}$ \\ ${ }^{1}$ Centro de Previsão de Tempo e Estudos Climáticos, Instituto Nacional de Pesquisas Espaciais \\ Rodovia Presidente Dutra, km 40, 12630-970 Cachoeira Paulista, SP, Brasil \\ ${ }^{2}$ Instituto de Aeronáutica e Espaço, Divisão de Ciências Atmosféricas \\ Praça Marechal Eduardo Gomes, 50, 12228-904 São José dos Campos, SP, Brasil \\ Manuscript received on December 18, 2006; accepted for publication on October 10, 2007; \\ contributed by CARLOS A. NOBRE*
}

\begin{abstract}
We developed a new world natural vegetation map at 1 degree horizontal resolution for use in global climate models. We used the Dorman and Sellers vegetation classification with inclusion of a new biome: tropical seasonal forest, which refers to both deciduous and semi-deciduous tropical forests. SSiB biogeophysical parameters values for this new biome type are presented. Under this new vegetation classification we obtained a consensus map between two global natural vegetation maps widely used in climate studies. We found that these two maps assign different biomes in $c a$. $1 / 3$ of the continental grid points. To obtain a new global natural vegetation map, non-consensus areas were filled according to regional consensus based on more than 100 regional maps available on the internet. To minimize the risk of using poor quality information, the regional maps were obtained from reliable internet sources, and the filling procedure was based on the consensus among several regional maps obtained from independent sources. The new map was designed to reproduce accurately both the large-scale distribution of the main vegetation types (as it builds on two reliable global natural vegetation maps) and the regional details (as it is based on the consensus of regional maps).
\end{abstract}

Key words: natural vegetation, tropical forest, biome, phytogeography, biogeophysical parameters, vegetation map.

\section{INTRODUCTION}

The vegetation cover of the Earth surface plays a recognized important role in global climate regulation (e.g. Charney 1975, Avissar et al. 2002). Thus, to perform more realistic climate simulations, it is essential to use global vegetation maps which are regionally reliable, as well as representing the broad spectrum of natural biomes. Atmospheric general circulation models (AGCM) used in weather and climate prediction or Earth System models require correct representation of the biophysical properties of the land surface, such as those which control the fluxes of radiation, momentum, sensible and latent heat, and trace gases. Since vegeta-

*Member Academia Brasileira de Ciências

Correspondence to: Marcos Daisuke Oyama

E-mail: daisuke_oyama@yahoo.com.br; oyama@iae.cta.br tion mediates all these land surface-atmosphere interactions, its accurate representation is mandatory in such models. Natural vegetation maps consider vegetation in its natural distribution without human action, while actual vegetation maps also consider anthropogenic land cover changes in ecosystems. The Centro de Previsão de Tempo e Estudos Climáticos/ Center for Ocean-LandAtmosphere Studies AGCM (CPTEC/COLA AGCM; Cavalcanti et al. 2002), for example, uses the actual vegetation map and vegetation classification of Dorman and Sellers (1989, DS89) for representation of surface processes. The DS89 classification considers 11 natural biomes and 1 agroecosystem (winter wheat cultivation). In some global change studies, such as prediction of global climate change impacts on Earth's biomes, or large scale paleoclimatic or paleoecological reconstruc- 
tion, it is recommended to use natural vegetation maps (instead of actual vegetations maps), since the past extension of agroecosystems and the factors regulating their future extension are not fully known. Furthermore, in land use change studies (e.g. Ramankutty and Foley 1999), it is useful to compare the distribution of modern croplands to global natural vegetation maps (natural vegetation maps are also referred to as potential vegetation maps, but here we use the term "natural" instead of "potential"; the latter is regarded as the vegetation type diagnosed only from climate), in order to access the consequences of human land use (Foley et al. 2005). However, there are only a few global natural vegetation maps available in the literature, and among them there are marked disagreements in several regions, as we will show here.

In this paper we report the development of a new global natural vegetation map, for use initially in climate studies with the CPTEC/COLA AGCM and with the CPTEC Potential Vegetation Model (Oyama and Nobre 2004). This new map builds on two global natural vegetation maps, which have been widely used by the scientific community, and in more than 100 regional land cover maps. To better represent the tropical biomes, we add a new vegetation type to DS89 classification and present its biogeophysical parameters in the context of SSiB land surface model (Xue et al. 1991). This new classification is hereafter called LONS08. A detailed account of the new map development is given in the following sections.

\section{IMPROVEMENT OF DS89 CLASSIFICATION}

The Küchler classification, on which DS89 is based, considers primarily physiognomic features of the vegetation. In the Küchler classification, vegetation types are described by a combination of letters and numbers that resembles the Köppen climate classification (Küchler 1988). For instance, D7 refers to broadleaf deciduous forest (D) with a 20-35 m tall canopy (7). The DS89 vegetation classification simply grouped the 32 main Küchler surface types into 12 major classes (see DS89, p. 838 , for further details).

The DS89 classification considers two forest types for the tropics: broadleaf-evergreen trees (type 1) and broadleaf-deciduous trees (type 2). From the DS89 map of natural vegetation (DS89, p. 839), it is clear that type 2 refers to tropical deciduous and semi-deciduous forests (such as in India) as well as to temperate deciduous forest (such as in North America and Europe). It is known that there are many differences between these two forest types, ranging from climate characteristics to the identity of the plant community per se. For example, the oak (Quercus sp.) is a typical tree of temperate deciduous forests, but it never occurs in tropical forests. Moreover, in the winter season of temperate regions, there is a marked reduction of sunlight, while in the tropics the incidence of light is practically the same throughout the year, which illustrates the difference in the very nature of deciduousness in tropical and temperate forests. While in middle latitudes all deciduous trees lose their leaves in a particular season, in the tropics some trees lose in an irregular basis, which is not closely related to temperature or light incidence rhythms, but mostly to water availability. For this reason, tropical trees presenting some degree of deciduousness have been named as "tropophyllous" plants (Küchler 1988). Thus, considering DS89 type 2 as referring strictly to deciduous temperate forests, it would be reasonable to include a new vegetation type in DS89 classification that would represent forests different from the evergreen type (type 1 in DS89) in tropical regions.

According to the dry season length and the amount of trees which lose their leaves, tropical forest formations can be classified in: (i) evergreen, (ii) seasonal semi-deciduous and (iii) seasonal deciduous (Eyre 1968, Barnes et al. 1998). In evergreen forests there is no occurrence of dry season (monthly precipitation always exceeds $100 \mathrm{~mm}$ ) and, due to this, phytocoenoses as a whole practically do not present deciduousness, standing permanently green (Eyre 1968, Odum 1983, Barnes et al. 1998, Schultz 2005). This kind of forest is found in Amazonia, South America Atlantic Forest, Equatorial Africa, west coast of India, Sri Lanka and Indo-Malaysia (where both evergreen and seasonal forests are found). This category also encompasses mixed evergreen forests, which occur in mountain regions, where gymnosperm and angiosperms elements are found within the same area (Barnes et al. 1998, Schultz 2005). On the other hand, seasonal forests have a dry period which ranges from 2-3 months in semi-deciduous to 5-6 months in 
deciduous forest. Within the dry season, 20 to $50 \%$ of trees in semi-deciduous forest, and up to $100 \%$ of trees in deciduous forest, lose their leaves. Therefore, seasonal tropical forests (semi-deciduous and deciduous) have a close relation with seasonal pulses of precipitation (Eyre 1968, Odum 1983, Barnes et al. 1998, Schultz 2005). This sort of forest occurs generally in the transition between evergreen forest and savannas: southern limit of Amazonia, inland Atlantic Forest, boundaries of the African rainforest, almost in entire India and in Southeastern Asia (mixed with evergreen forest).

Although semi-deciduous and deciduous tropical forests have some distinct characteristics, they could be conveniently considered as belonging to just a single category. This is justified because, in the tropics, the distribution of deciduous forests is small (Eyre 1968, Barnes et al. 1998, Ramankutty and Foley 1999), and the great majority of seasonal forests fits better, due to climatological and biological reasons, into the semi-deciduous or semi-evergreen category (except in India, where very dry forests with pronounced deciduousness are found) (Eyre 1968, Barnes et al. 1998, Schultz 2005). Furthermore, for the purpose of AGCM simulations, it is desirable to classify vegetation with a minimum possible number of categories, since it is necessary to prescribe a large amount of physical and physiological parameters to each vegetation type ( $c f$. Sellers et al. 1986, Xue et al. 1991). Then, while from now on referring to type 1 (tropical forest) exclusively as tropical evergreen forest, we suggest that the following biome be added to the DS89 classification:

Tropical seasonal forest: encompassing semi-deciduous and deciduous tropical forests. It has close resemblance with tropical evergreen forests, but, contrastingly, the plant community phenological pattern is clearly and strongly influenced by precipitation seasonality.

The 11 natural biome types of DS89 plus the new type (tropical seasonal forest, hereafter considered as type 13) compounds LONS08 classification (Table I).

\section{SSIB PARAMETERS FOR TROPICAL SEASONAL FOREST}

In the SSiB model (Xue et al. 1991), a set of values representing a large number of biogeophysical parameters is assigned to each biome. For the proposed biome, tropical seasonal forest, the SSiB parameters values are shown in Tables II and III on a tentative basis [for future work, the biophysical parameters could be calibrated using data collected in a tropical seasonal forest site in Sinop (Southern Amazonia, Brazil; Vourlitis et al. 2001)]. It is assumed that tropical seasonal and evergreen forests have the same plant physiological and soil parameters' value. Leaf area index, green fraction, roughness length and displacement height are derived from Normalized Difference Vegetation Index (NDVI) data over undisturbed seasonal forest regions in South America and Africa (from ISLSCP2; Los et al. 2000). Canopy height $\left(z_{t}\right)$ is evaluated from the displacement height $(d)$ by assuming a linear relation between $z_{t}$ and $d: z_{t}=d / 0.78$, where 0.78 is valid for both tropical evergreen forest and savanna. The assumption of linear relation between $z_{t}$ and $d$ is found in other studies (e.g. Wright et al. 1996, p. 490). The parameters for bulk boundary layer resistance $\left(c_{b}\right)$ and aerodynamic resistance between soil surface and canopy air space $\left(c_{d}\right)$ are estimated from

$$
\begin{aligned}
& c_{b}=-12.177 \cdot z_{0}+37.713 \quad \text { and } \\
& c_{d}=78.478 \cdot \ln z_{0}+239.59,
\end{aligned}
$$

where $z_{0}$ is the roughness length (m). These relations were adjusted using the annual average values of $c_{b}, c_{d}$ and $z_{0}$ for 5 biomes: tropical evergreen forest (biome 1), temperate forest (2), savanna (6), shrubland ("caatinga", 8 ) and semi-desert vegetation (9).

\section{THE NEW VEGETATION MAP}

\section{CONSENSUS MaP}

We used the natural vegetation maps of Ramankutty and Foley (1999, RF99) and Matthews (1983, M83), both at 1 degree horizontal resolution, to obtain a consensus map between them. These two maps (hereafter referred to as base-maps) classify vegetation in very distinct forms: RF99 map classification has 15 categories, while M83 has 32. The classification used in RF99 map is derived from the Olson Global Ecosystems (OGE) framework, which originally has 94 vegetation types (Olson 1994). The M83 map classification is based on UNESCO's, that groups the world vegetation in 225 types according to its physiognomy, latitude, deciduousness, altitude etc 
TABLE I

LONS08 vegetation classification.

\begin{tabular}{c|l|l}
\hline Number & \multicolumn{1}{|c}{ Shorthand name } & \multicolumn{1}{c}{ Description } \\
\hline 1 & tropical evergreen forest & tropical broadleaved evergreen trees \\
\hline 2 & temperate forest & temperate deciduous trees \\
\hline 3 & mixed forest & temperate/boreal broadleaved and needleleaved trees \\
\hline 4 & boreal evergreen forest & boreal needleleaved evergreen trees \\
\hline 5 & boreal seasonal forest & boreal needleleaved deciduous trees \\
\hline 6 & savanna & tropical broadleaved raingreen trees with grass groundcover \\
\hline 7 & grasslands & temperate grass groundcover only \\
\hline 8 & shrubland & tropical broaleaved shrubs with grass groundcover \\
\hline 9 & semi-desert & tropical/temperate broadleaved shrubs with bare soil \\
\hline 10 & tundra & boreal/alpine dwarf trees and shrubs with grass groundcover \\
\hline 11 & desert & bare soil \\
\hline 13 & tropical seasonal forest & tropical broadleaved raingreen trees \\
\hline 20 & ice & permanent ice \\
\hline
\end{tabular}

TABLE II

Time invariant $\mathrm{SSiB}$ parameters for the new tropical seasonal forest biome type (see text for detailed description).

\begin{tabular}{l|c}
\hline \multicolumn{1}{c|}{ Parameter } & Value \\
\hline Leaf stomatal resistance coefficients & \\
$a\left(\mathrm{~J} \mathrm{~m}^{-3}\right)$ & 2335.9 \\
$b\left(\mathrm{~W} \mathrm{~m}^{-2}\right)$ & 0.0145 \\
$c\left(\mathrm{~s} \mathrm{~m}^{-1}\right)$ & 153.49 \\
\hline Leaf angle orientation & 0.1 \\
\hline Optimum temperature for stomatal functioning $(\mathrm{K})$ & 303 \\
\hline Minimum temperature for stomatal functioning $(\mathrm{K})$ & 273 \\
\hline Maximum temperature for stomatal functioning $(\mathrm{K})$ & 318 \\
\hline Constant for water vapor deficit adjustment $\left(\mathrm{hPa}{ }^{-1}\right)$ & 0.0273 \\
\hline Constant for moisture adjustment & \\
$c_{1}$ & 1.2 \\
$c_{2}$ & 6.25 \\
\hline Rooting depth (m) & 1 \\
\hline$B$ soil parameter & 7.12 \\
\hline Soil moisture potential at saturation $(\mathrm{m})$ & -0.086 \\
\hline Soil hydraulic conductivity at saturation $\left(\mathrm{m} \mathrm{s}{ }^{-1}\right)$ & 0.00002 \\
\hline Soil porosity & 0.42 \\
\hline Thickness of 3 soil layers (m) & 0.02 \\
surface layer (1st) & 1.48 \\
root layer (2nd) & 2 \\
\hline drainage layer (3rd) & 27 \\
\hline Height of canopy top (m) & \\
\hline
\end{tabular}


TABLE III

Time-varying biophysical parameters (LAI, green fraction, vegetation cover, roughness length and displacement height) are derived from NDVI data; the parameters $c_{b}$ and $c_{d}$ are estimated from $z_{0}$. Values shown are valid for Northern Hemisphere (NH; for Southern Hemisphere, a 6 month-shift is necessary to account for interhemispheric seasonality difference).

\begin{tabular}{|c|c|c|c|c|c|c|c|}
\hline $\begin{array}{l}\text { Month } \\
\text { (NH) }\end{array}$ & $\begin{array}{c}\text { Leaf area } \\
\text { index } \\
\left(\mathrm{m}^{2} \mathrm{~m}^{-2}\right)\end{array}$ & $\begin{array}{l}\text { Green } \\
\text { fraction }\end{array}$ & $\begin{array}{c}\text { Vegetation } \\
\text { cover }\end{array}$ & $\begin{array}{c}\text { Roughness } \\
\text { length } \\
\text { (m) }\end{array}$ & $\begin{array}{l}\text { Displacement } \\
\text { height } \\
\text { (m) }\end{array}$ & $\begin{array}{c}\text { Parameter for bulk } \\
\text { boundary layer } \\
\text { resistance } \\
\left(c_{b}\right)\end{array}$ & $\begin{array}{l}\text { Parameter for aero- } \\
\text { dynamic resistance } \\
\text { between soil surface } \\
\text { and canopy air space } \\
\qquad\left(c_{d}\right)\end{array}$ \\
\hline Jan & 3.15 & 0.732 & 0.98 & 1.89 & 21.07 & 14.7 & 289.66 \\
\hline Feb & 3.03 & 0.729 & 0.98 & 1.88 & 21.01 & 14.8 & 289.03 \\
\hline Mar & 2.97 & 0.728 & 0.98 & 1.87 & 20.97 & 15.0 & 288.64 \\
\hline Apr & 2.94 & 0.707 & 0.98 & 1.84 & 20.86 & 15.2 & 287.65 \\
\hline May & 2.88 & 0.718 & 0.98 & 1.84 & 20.86 & 15.2 & 287.65 \\
\hline Jun & 2.97 & 0.740 & 0.98 & 1.87 & 20.97 & 15.0 & 288.64 \\
\hline Jul & 3.15 & 0.774 & 0.98 & 1.93 & 21.24 & 14.3 & 291.06 \\
\hline Aug & 4.89 & 0.839 & 0.98 & 1.95 & 21.40 & 14.0 & 291.89 \\
\hline Sep & 4.60 & 0.801 & 0.98 & 1.94 & 21.36 & 14.0 & 291.78 \\
\hline Oct & 4.13 & 0.780 & 0.98 & 1.94 & 21.32 & 14.1 & 291.58 \\
\hline Nov & 3.73 & 0.726 & 0.98 & 1.92 & 21.22 & 14.3 & 290.94 \\
\hline Dec & 3.26 & 0.753 & 0.98 & 1.89 & 21.07 & 14.7 & 289.66 \\
\hline
\end{tabular}

(UNESCO 1988). In order to obtain these maps under the LONS08 classification, it was necessary to relate RF99 and M83 map classifications to LONS08. It was accomplished in two steps: firstly, the M83 map categories were related to RF99 map categories; and then the RF99 map categories were related to LONS08 types.

To find the relation between the M83 and RF99 map classifications, we followed a semi-objective procedure. Consider the biome $i$ of M83 map classification, and $N_{i j}$ as the number of grid points classified as $i$ in M83 map and $j$ in RF99 map. The fraction of grid points classified as biome $i$ in M83 map and $j$ in RF99 map is given by

$$
F_{i j}=\frac{N_{i j}}{N_{i}}, N_{i}=\sum_{j} N_{i j} .
$$

Let $J_{1}$ and $J_{2}$ be the biomes of RF99 associated respectively with the first and second major fraction value. Then the biome $i$ of M83 map classification was associated to biome $j$ of RF99 when one the following objective criteria was met: $F_{i J 1} \geq 0,7$ (greater than $70 \%$ ) [represented by * in Table IV]; or $0,4 \leq F_{i J 1} \leq 0,7$ (between 40 and $70 \%$ ) and $F_{i J 2} \leq 0,2$ (lower than 20\%) [represented by ${ }^{* *}$ in Table IV]. If these criteria were not satisfied, biome $i$ of M83 map classification was associated (subjectively) to a RF99 biome (represented by *** in Table IV) based on the biomes definition and/or their geographic distribution. With the procedure here described we grouped the 32 M83 types into the 15 of RF99 (Table IV).

The relation between the categories of RF99 map classification and LONS08 types was obtained subjectively, based only on the biomes definition and/or their geographic distribution (Table V). Both base-maps are shown under LONS08 classification in Figures 1a and 1b. These maps show only a "fair" agreement according to the kappa statistics (Monserud and Leemans 1992) $(\kappa=0.49)$. Our indirect relation between vegetation types of M83 map classification and LONS08 is similar to that obtained by Sellers et al. (1996).

With the base-maps maps under the same classification (LONS08), we elaborated the consensus map, i.e. a map that shows only the grid points for which both base-maps assign the same biome (Fig. 1c). The consensus areas were mainly found in tropical forest and 
TABLE IV

Relation between M83 and RF99 classifications. A * denotes conversion of M83

biome to one of RF99 when $F_{i J 1} \geq 0.7$; ** when $0.4 \leq F_{i J 1} \leq 0.7$ and $F_{i J 2} \leq 0.2$; and $* * *$ when it did not satisfied both of the two above criteria, then M83 biome $i$ was subjectively associated with one of RF99 (see text for detailed explanation). RF99 vegetation type names are found in Table $V$.

\begin{tabular}{|c|c|c|}
\hline & M83 & RF99 \\
\hline 0 & Water & $0 *$ \\
\hline 1 & tropical evergreen rainforest & $1 *$ \\
\hline 2 & tropical/subtropical evergreen seasonal broadleaved forest & $1 * *$ \\
\hline 3 & subtropical evergreen rainforest & $2 * * *$ \\
\hline 4 & temperate/subpolar evergreen rainforest & $8 * * *$ \\
\hline 5 & temperate evergreen seasonal broadleaved forest, summer rain & $3 * * *$ \\
\hline 6 & evergreen broadleaved sclerophyllous forest, winter rain & $3 * *$ \\
\hline 7 & tropical/subtropical evergreen needleleaved forest & $4 * * *$ \\
\hline 8 & temperate/subpolar evergreen needleleaved forest & $6 * * *$ \\
\hline 9 & tropical/subtropical drought-deciduous forest & $2 * *$ \\
\hline 10 & cold-deciduous forest, with evergreens & $5 * * *$ \\
\hline 11 & cold-deciduous forest, without evergreens & $7 * * *$ \\
\hline 12 & xeromorphic forest/woodland & $11 * *$ \\
\hline 13 & evergreen broadleaved sclerophyllous woodland & $9 * *$ \\
\hline 14 & evergreen needleleaved woodland & $6 * * *$ \\
\hline 15 & tropical/subtropical drought-deciduous woodland & $9 * * *$ \\
\hline 16 & cold-deciduous woodland & $8 * *$ \\
\hline 17 & evergreen broadleaved shrubland/thick, evergreen dwarf-shrubland & $12 * * *$ \\
\hline 18 & evergreen needleleaved or microphyllous shrubland/thicket & $8 * *$ \\
\hline 19 & drought-deciduous shrubland/thicket & $12 * *$ \\
\hline 20 & cold-deciduous subalpine/subpolar shrubland/dwarf shrub & $13 * * *$ \\
\hline 21 & xeromorphic shrubland/dwarf shrubland & $12 * * *$ \\
\hline 22 & arctic/alpine tundra, mossy bog & $13 * * *$ \\
\hline 23 & tall/medium/short grassland, $10-40 \%$ woody cover & $9 * *$ \\
\hline 24 & tall/medium/short grassland, $<10 \%$ woody cover & $9 * *$ \\
\hline 25 & tall/medium/short grassland, shrub cover & $10 * * *$ \\
\hline 26 & tall grassland, no woody cover & $10 * * *$ \\
\hline 27 & medium grassland, no woody cover & $10 * *$ \\
\hline 28 & meadow, short grassland, no woody cover & $10 * *$ \\
\hline 29 & forb formations & $13 * *$ \\
\hline 30 & desert & $14 * *$ \\
\hline 31 & ice & $15^{*}$ \\
\hline
\end{tabular}

desert regions. More than $30 \%$ of the continental areas did not show consensus between the two base-maps (white areas in Fig. 1c), which partially explains the only "fair" agreement revealed by the kappa statistics. However, it is remarkable that $70 \%$ of agreement results from two maps obtained from quite different sources and methods, what denotes their good quality.

\section{Non-CONSENSUS AREAS}

In order to fill the non-consensus areas between RF89 and M83 maps, we consulted more than 100 regional natural vegetation maps available on the internet. Although actual land cover data (e.g. from VGT GLC2000, MODIS Modland, AVHRR DisCover) have a great 

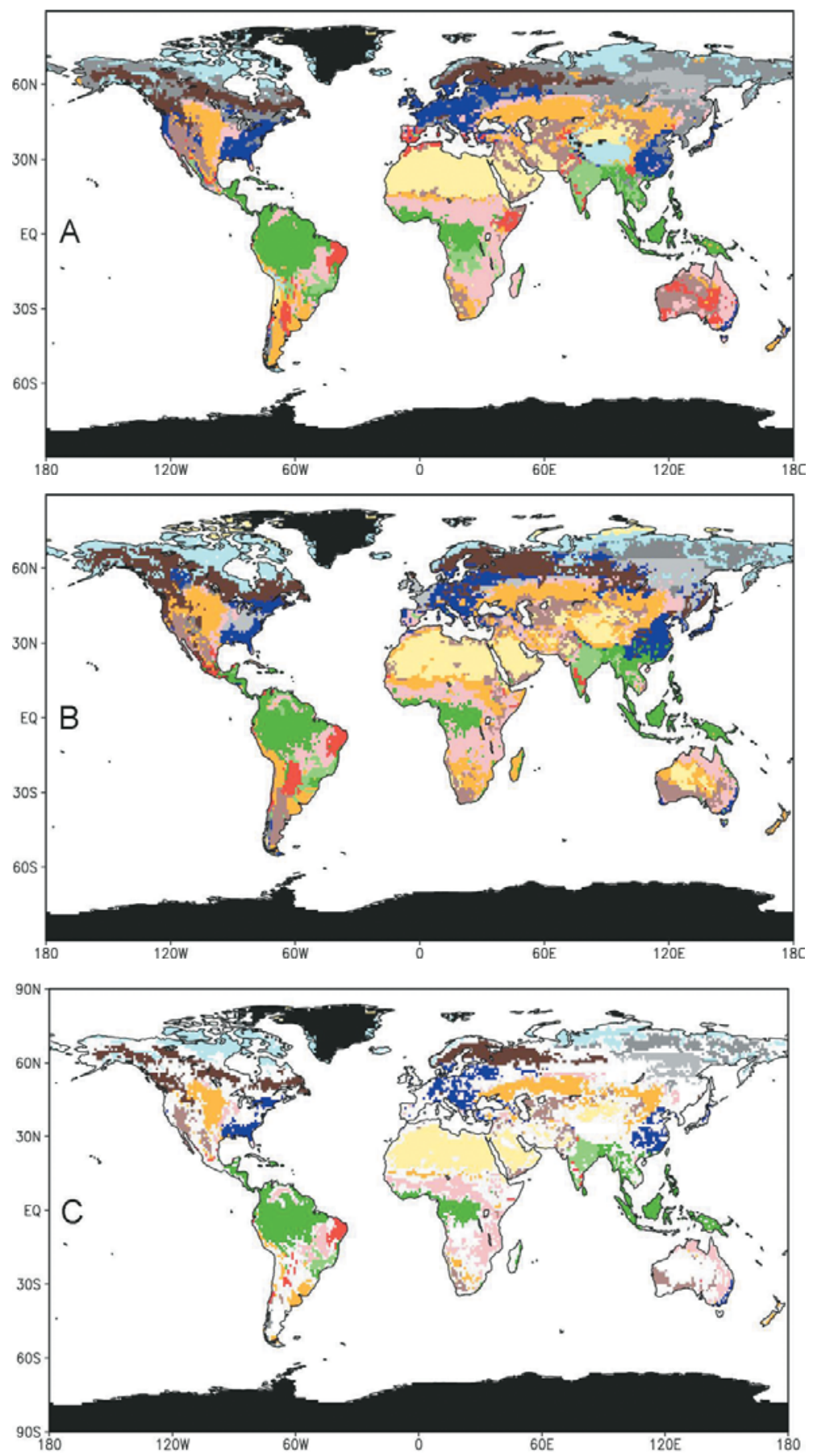

$\square 1$ Tropical Evergreen Forest

2 Temperate Forest

$\square 5$ Boreal Seasonal Forest

$\square 9$ Semi-desert

$\square 3$ Mixed Forest

$\square 6$ Savanna

$\square 10$ Tundra

4 Boreal Evergreen Forest

$\square 7$ Grasslands

$\square 11$ Desert

$\square 13$ Tropical Seasonal Forest

प20 Ice

Fig. 1 - Natural vegetation maps under LONS08. (A) Ramankutty and Foley (1999), (B) Matthews (1983) and $(\mathrm{C})$ consensus between them. In $(\mathrm{C})$, white continental grid points represent non-consensus areas. 
TABLE V

Relation between RF99 and LONS08 classifications.

\begin{tabular}{l|l||l|l}
\hline & \multicolumn{1}{|c||}{ RF99 } & & \multicolumn{1}{c}{ LONS08 } \\
\hline 0 & water & 0 & water \\
1 & tropical evergreen forest & 1 & tropical evergreen forest \\
2 & tropical deciduous forest & 13 & tropical seasonal forest \\
3 & temperate broadleaf evergreen forest & 2 & temperate forest \\
4 & temperate needleleaf evergreen forest & 2 & temperate forest \\
5 & temperate deciduous forest & 2 & temperate forest \\
6 & boreal evergreen forest & 4 & boreal evergreen forest \\
7 & boreal deciduous forest (larch) & 5 & boreal seasonal forest \\
8 & mixed forest & 3 & mixed forest \\
9 & savanna & 6 & savanna \\
10 & grassland & 7 & grasslands \\
11 & dense shrubland & 8 & shrubland \\
12 & open shrubland & 9 & semi-desert \\
13 & tundra & 10 & tundra \\
14 & desert & 11 & desert \\
15 & ice & 20 & ice \\
\hline
\end{tabular}

potential for supporting studies on natural and anthropogenic vegetation distribution, they would not be of great advantage in the current study. That is because most of the non-consensus areas showed in Figure 1c are found in regions no longer covered by natural vegetation (e.g. United States, Europe and Central Asia). Then, in order to obtain the present new map, we had to rely just on maps accounting for the natural vegetation which once existed in these regions. Regional maps were used at this part of the work (instead of additional global maps), because they provide a more accurate vegetation distribution and a more detailed vegetation description on a regional scale. Most of the maps belong to the Perry Castañeda Library Map Collection at University of Texas (http://www.lib.utexas.edu/maps) where original maps were scanned and made available on the World Wide Web. Other digital maps, not present in that collection, such as the natural vegetation map of Brazil (IBGE 1993) and Alaska (Küchler 1966), were also used. We filled the non-consensus areas separately to lowland (continental areas with elevations $<1000 \mathrm{~m}$ ) and upland areas (elevations $>1000 \mathrm{~m}$ ). This procedure was adopted to allow for a detailed focus on high elevation areas, due to the difficulty in selecting a representative biome in very steep regions (because of vegetation altitudinal zonation) and the fact that in elevated regions extra-tropical biomes may occur within tropical latitudes.

The use of digital maps available on the internet is a low-cost alternative to the use of comprehensive collections of scientific paper based maps. However, it is widely recognized that information available on the internet cannot always be regarded as reliable (e.g., Eysenbach and Diepgen 1998). To minimize the risks of using poor quality information, (i) most of the maps came from reliable internet sites (e.g., University of Texas, USDA, IBGE) and (ii) the filling procedure was based on the consensus among several regional maps obtained from independent sources. The constraint of regional consensus not only filters out poor quality maps, but also assures that the new map is not biased towards a particular regional (or global) map.

For a given non-consensus region, we obtained the consensus among at least two regional maps of recognized different sources. Then, we related the LONS08 categories to the vegetation types shown in the regional maps. Since regional maps usually consider more vegetation categories than LONS08, and the categories are often referred to by using local names, we also examined photographs of the vegetation types available on the internet to facilitate the subjective grouping of the regional 
maps categories. Regions of non-consensus were filled (grid) point by point, according to the consensus among the regional maps.

Table VI presents the main regions of non-consensus (lowlands and uplands), what the base-maps allocates in each region, which base-map resembles better the regional maps consensus, and some remarks on how these areas were filled.

\section{Minor Consensus ModificAtion}

We verified from the regional maps consensus that there were consensus areas between the base-maps which did not correspond to the best representation (i.e. the consensus between RF99 and M83 did not correspond to the regional consensus). These areas were changed according to the regional consensus.

South America Atlantic Forest: some grid points with tropical seasonal forests were changed to savanna and vice versa.

Eastern North America and Eastern Europe: some temperate forest areas were changed to mixed forest (see the region on Table VI).

Central Russia: some mixed forest areas were changed to boreal seasonal forest (see the region on Table VI).

\section{DISCUSSION}

The new global natural vegetation map is shown in Figure 2. Unlike the RF99, this new map must be closer to represent the world's natural vegetation in preagricultural times, since the majority of the regional maps used display natural primary (instead of potential secondary) vegetation. Both base-maps presented a similar level of agreement with the new map (RF99 $\times$ new map: $\kappa=0.60 ; \mathrm{M} 83 \times$ new map: $\kappa=0.58)$ meaning that no base-map could be regarded as the most representative of the regional consensus.

The biomes distribution in some regions could be a subject of concern, in view of the fact that LONS08 is restricted only to 13 phytophysiognomic types. For instance, shrubland (caatinga, type 8) was found in extratropical regions, such as in Spain and Australia; savanna (type 6), in Southern Africa; and tropical seasonal forest (type 13), in Northeast Argentina. Thus, from a climatic point of view, an inconsistency could be noticed: the occurrence of "tropical" types (caatinga-type shrubland, savanna and tropical seasonal forest) in extratropical latitudes. This climatic inconsistency is due to deficiencies in the LONS08 vegetation classification. For the tropics, LONS08 has biomes of arboreal (tropical forests), arboreal-grassy (savanna) and arbustivegrassy (caatinga-type shrubland) physiognomies. For extra-tropical regions, there are only biomes with arboreal (temperate forests) and grassy (grasslands) physiognomies, what reveals the lack of an "extra-tropical savanna or shrubland". This could be a new vegetation type to be included in LONS08 (in Spain, this new type would be more appropriate than tropical caatinga-type shrubland or grasslands). This classification inconsistency and thus the incorrect representation of land surface properties have the potential to generate errors in the output of climate models, although the new type cited above would cover a relatively small area ( $c a .200$ grid points).

The new global natural vegetation map developed in this study may be regarded as an advancement for the representation of tropical vegetation in comparison to DS89 classification, after the inclusion of the tropical seasonal forest type. The lack of consensus among the basemaps revealed that these maps, which have been widely used in climate studies, diverge considerably (more than $30 \%$ of the continental grid points were non-consensus areas).

Recent trends in climate modeling and land surface processes studies point to future models running at higher resolutions and relying on more than a dozen vegetation cover types. However, presently in most global climate change studies, for instance in IPCC AR4 (IPCC 2007), the majority of GCMs used run at coarse horizontal resolution (about 2.5 degrees; the highest resolution is 1.4 degrees in the CCSM3-NCAR GCM). Additionally, the inclusion of more vegetation categories demands more effort on field measurement of vegetation properties in order to feed GCMs with calibrated values of biophysical parameters. These considerations justify the construction of the present map on 1 degree horizontal resolution and containing a restricted set of vegetation categories, although we recognize the trend of increasing model resolution in global climate models, which will drive the need of defining more vegetation classes. The simple methodology described in here can be used to 
TABLE VI

The main non-consensus regions between M83 and RF99 maps. In the first column, $L$ refers to lowland regions (elevation $<1000 \mathrm{~m}$ ), and $\mathrm{U}$ to upland regions (elevation $>1000 \mathrm{~m}$ ). Caatinga refers to tropical shrubland (type 8 of $\mathbf{L O N S 0 8}$ ).

\begin{tabular}{|c|c|c|c|c|c|}
\hline & \multirow{2}{*}{ Region } & \multicolumn{2}{|c|}{ Coverage shown by each base-map } & \multirow{2}{*}{$\begin{array}{l}\text { Base-map closer to } \\
\text { regional consensus }\end{array}$} & \multirow{2}{*}{ Remarks } \\
\hline & & RF99 & M83 & & \\
\hline $\mathrm{L}$ & Southern South America & $\begin{array}{l}\text { Savanna (Chaco) and grasslands } \\
\text { (Patagonia and Chaco) }\end{array}$ & $\begin{array}{l}\text { Caatinga (Chaco) and } \\
\text { semi-desert (Patagonia) }\end{array}$ & M83 & $\begin{array}{l}\text { Argentine Espinal represented } \\
\text { partially in both base-maps }\end{array}$ \\
\hline $\mathrm{L}$ & Sahel & Mainly grasslands & Mainly grasslands & none & $\begin{array}{l}\text { Both base-maps do not consider } \\
\text { caatinga in the transition between } \\
\text { savanna and Sahara desert }\end{array}$ \\
\hline $\mathrm{L}$ & $\begin{array}{l}\text { Ethiopia, Somalia } \\
\text { and Kenya }\end{array}$ & Caatinga and semi-desert & Savanna and grasslands & RF99 & $\begin{array}{l}\text { Above } 1000 \mathrm{~m} \text { we have } \\
\text { allocated tropical forests }\end{array}$ \\
\hline $\mathrm{L}$ & $\begin{array}{l}\text { Alaska and Western } \\
\text { Canada }\end{array}$ & Mixed forest & Boreal forest and tundra & M83 & $\begin{array}{l}\text { Too much high latitudes to } \\
\text { hold mixed forests }\end{array}$ \\
\hline $\mathrm{L}$ & Eastern North America & $\begin{array}{l}\text { Temperate forest (south) and } \\
\text { mixed forest (north) }\end{array}$ & $\begin{array}{l}\text { Temperate forest (south and } \\
\text { north) and larch (center) }\end{array}$ & none & $\begin{array}{l}\text { Southeastern USA has elements } \\
\text { of boreal, temperate and } \\
\text { subtropical forests }\end{array}$ \\
\hline $\mathrm{L}$ & Western Europe & $\begin{array}{l}\text { Caatinga (Spain) and temperate } \\
\text { forest (France and UK) }\end{array}$ & $\begin{array}{l}\text { Savanna (Spain) and larch } \\
\text { (France and UK) }\end{array}$ & RF99 & $\begin{array}{l}\text { Caatinga seems not to be very } \\
\text { adequate to represent the } \\
\text { Mediterranean vegetation }\end{array}$ \\
\hline $\mathrm{L}$ & Eastern Europe & $\begin{array}{l}\text { Mixed and temperate forests, } \\
\text { and savanna }\end{array}$ & $\begin{array}{l}\text { Larch, boreal and } \\
\text { temperate forests }\end{array}$ & none & $\begin{array}{l}\text { Both base-maps do not consider } \\
\text { mixed forest as an ecotone } \\
\text { between temperate and } \\
\text { boreal forests }\end{array}$ \\
\hline $\mathrm{L}$ & Central Russia & Mixed forest & $\begin{array}{l}\text { Mixed (north) and } \\
\text { boreal forests }\end{array}$ & none & $\begin{array}{l}\text { Both base-maps underestimate } \\
\text { larch coverage in the region }\end{array}$ \\
\hline $\mathrm{L}$ & Eastern Asia & $\begin{array}{l}\text { Mixed forest and savanna } \\
\text { (Manchuria) }\end{array}$ & $\begin{array}{l}\text { Larch and boreal forests, } \\
\text { and savanna (Manchuria) }\end{array}$ & RF99 & $\begin{array}{l}\text { We considered grasslands } \\
\text { (instead of savanna) as more } \\
\text { suitable for Manchuria }\end{array}$ \\
\hline $\mathrm{L}$ & Australia & $\begin{array}{l}\text { Semi-desert, caatinga } \\
\text { and savanna }\end{array}$ & $\begin{array}{l}\text { Desert, semi-desert, } \\
\text { grasslands and savanna }\end{array}$ & none & $\begin{array}{l}\text { Australia does not have large } \\
\text { desert areas, but has large } \\
\text { extensions of semi-deserts }\end{array}$ \\
\hline $\mathrm{U}$ & Himalayas & Tundra and desert & Desert & M83 & $\begin{array}{l}\text { R99 overestimates tundra } \\
\text { extension in the region (M83 } \\
\text { allocates tundra only in } \\
\text { latitudes above } 60^{\circ} \text { ) }\end{array}$ \\
\hline $\mathrm{U}$ & African plateau & $\begin{array}{l}\text { Tropical seasonal forest } \\
\text { and savanna }\end{array}$ & Savanna and grasslands & RF99 & $\begin{array}{l}\text { The } 1000 \mathrm{~m} \text { height seems to be } \\
\text { the boundary between tropical } \\
\text { seasonal forest and savanna }\end{array}$ \\
\hline $\mathrm{U}$ & Andes & Desert, tundra and grasslands & Grasslands & RF99 & $\begin{array}{l}\text { M83 allocates tundra only in } \\
\text { latitudes above } 60^{\circ} ; \text { R99 } \\
\text { represents well the } \\
\text { Atacama desert }\end{array}$ \\
\hline $\mathrm{U}$ & Rocky Mountains & $\begin{array}{l}\text { Semi-desert and temperate } \\
\text { forest (in very high altitudes) }\end{array}$ & $\begin{array}{l}\text { Semi-desert, grasslands and } \\
\text { mixed and boreal forests } \\
\text { (in very high altitudes) }\end{array}$ & M83 & $\begin{array}{l}\text { RF99 overestimates semi-desert } \\
\text { extension in the northern } \\
\text { part of the region }\end{array}$ \\
\hline
\end{tabular}

produce vegetation maps with higher spatial resolution and with more vegetation classes. Currently, a 0.5 degree resolution natural vegetation map (partially based on the 1 degree map constructed here) has been developed to be used in regional climate model simulations (L.F. Salazar, personal communication).

The use of this new vegetation map, just like the base-maps, is not restricted to be used as reference map for AGCM, but can also be useful (as reference map) for global land cover change studies [e.g. evaluation of historical land use changes (similar to RF99)] and for the assessment of global climate change impacts on vegetation distribution (e.g. Salazar et al. 2007). The improved representation of vegetation distribution may provide a more accurate rendition of large-scale biome-climate interactions. 


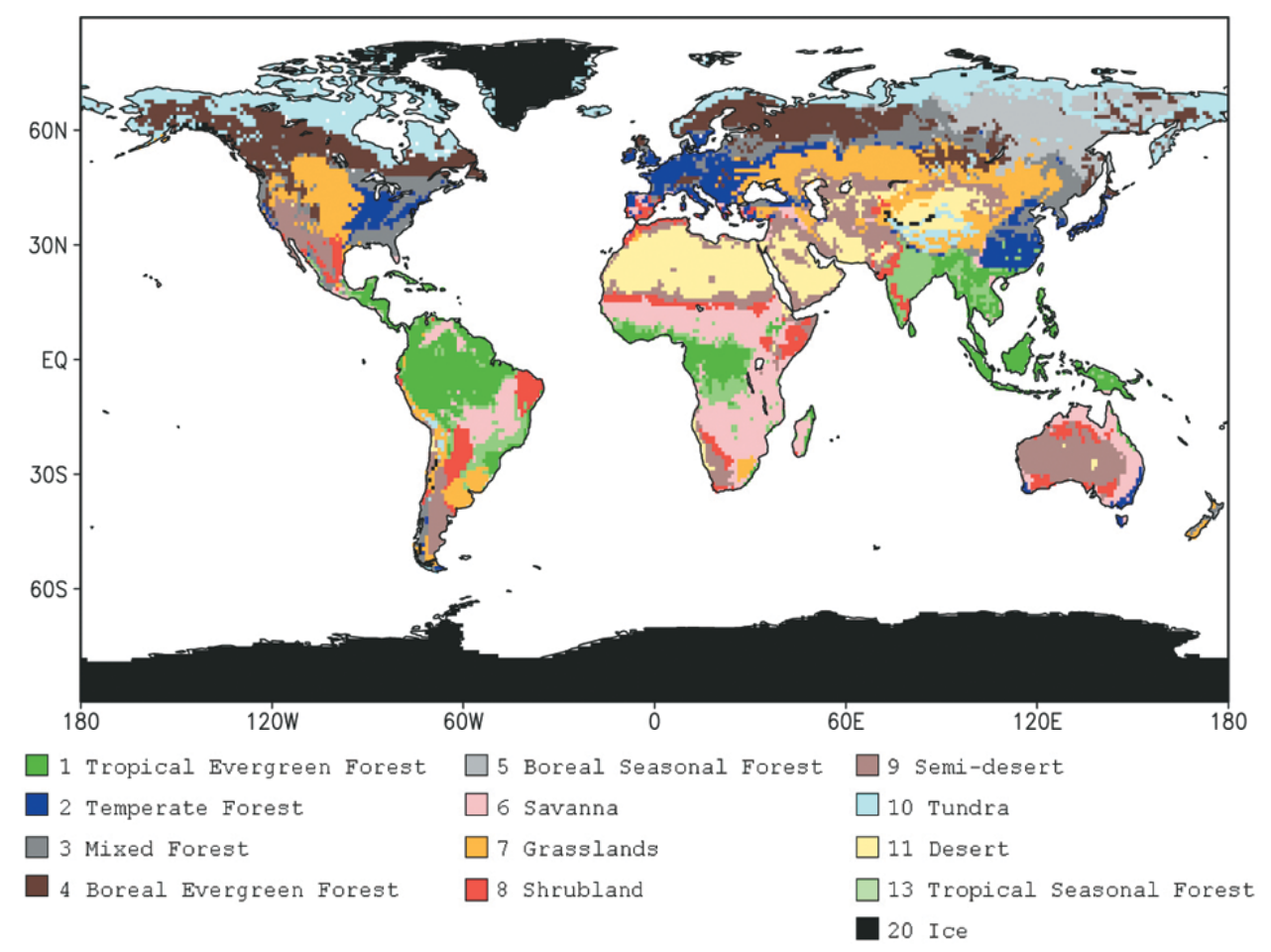

Fig. 2 - The new global natural vegetation map under LONS08 classification.

\section{ACKNOWLEDGMENTS}

This work is part of the first author's MSc thesis under the guidance of the second and third authors. We wish to thank Fundação de Amparo à Pesquisa do Estado de São Paulo (FAPESP) for the financial support (DML Proc. no. 04/12235-3) and three anonymous reviewers for helpful comments on this manuscript.

\section{RESUMO}

Elaborou-se um novo mapa global de vegetação natural na resolução horizontal de 1 grau para uso em modelos climáticos de circulação geral. Utilizou-se a classificação de vegetação de Dorman e Sellers com a inclusão de um novo bioma: floresta tropical estacional, que compreende as florestas tropicais decíduas e semidecíduas. Para este novo tipo de bioma, apresentaram-se os valores de parâmetros biogeofísicos do modelo de processos à superfície $\mathrm{SSiB}$. Sob essa nova classificação de vegetação, obteve-se um mapa de consenso entre dois mapas globais de vegetação natural amplamente utilizados em estudos climáticos. Mostrou-se que esses dois mapas alocam biomas diferentes em cerca de $1 / 3$ dos pontos de grade continentais. Para obter um novo mapa global de vegetação natural, as áreas de não-consenso foram preenchidas utilizando-se um conjunto de mais de 100 mapas regionais disponíveis na Internet. Para minimizar os riscos de se usar informação de baixa qualidade, os mapas regionais foram obtidos de sítios confiáveis da Internet, e o procedimento de preenchimento baseou-se no consenso entre vários mapas regionais obtidos de fontes independentes. Elaborou-se o novo mapa de modo a reproduzir em grande escala a distribuição dos principais tipos de vegetação (uma vez que se pauta em dois mapas globais de vegetação natural confiáveis) e também detalhes regionais (uma vez que se baseia em consenso de mapas regionais) com precisão.

Palavras-chave: vegetação natural, floresta tropical, bioma, fitogeografia, parâmetros biogeofísicos, mapa de vegetação.

\section{REFERENCES}

Avissar R, Dias PlS, Dias MAFS and Nobre CA. 2002. The large-scale biosphere-atmosphere experiment in Amazonia (LBA): insights and future research needs. J Geophys Res Atmos 97: 2729-2742.

BARnes BV, ZAK DR, DENTON SR AND SPURR SH. 1998. Forest ecology, $4^{\text {th }}$ ed., New York: J Wiley \& Sons, $792 \mathrm{p}$. 
CAVAlCANTI IFA ET AL. 2002. Global climatological features in a simulation using the CPTEC-COLA AGCM. J Climate 15: 2965-2988.

ChARneY JG. 1975. The dynamics of deserts and droughts. Q J Roy Met Soc 101: 193-202.

Dorman JL AND SEllers PJ. 1989. A global climatology of albedo, roughness length and stomatal resistance for atmospheric general circulation models as represented by the Simple Biosphere model (SiB). J Appl Meteorol 28: $833-855$.

EYRE SR. 1968. Vegetation and soils, a world picture, $2^{\text {nd }}$ ed., London: Edward Arnold Publishers, 328 p.

Eysenbach G And Diepgen TL. 1998. Towards quality management of medical information on the internet: evaluation, labelling and filtering of information. Brit Med J 317: 1496-1500

FOLEY JA ET AL. 2005. Global consequences of land use. Science 309: 570-574.

INSTITUTO BRASILEIRo DE GEOGRAFIA E EstatísticA (IBGE). 1993. Mapa de vegetação do Brasil. Rio de Janeiro: IBGE.

Intergovernmental Panel on Climate Change (IPCC). 2007. Climate change 2007: the physical science basis (summary for policymakers), Geneva: IPCC Secretariat, $18 \mathrm{p}$.

KÜCHLER AW. 1988. A physiognomic and structural analysis of vegetation. In: KÜCHLER AW AND ZONNEVELD IS (Eds), Vegetation Mapping, Dordrecht: Kluwer Academic Publishers, p. 37-50.

KÜCHLER AW. 1966. Potential natural vegetation of Alaska. Kansas: University of Kansas.

Los SO, Collatz GJ, Sellers PJ, Malmström CM, Pollack NH, Defries RS, Bounoua L, Parris MT, TuCKer CJ AND DAZlich DA. 2000. A global 9-year biophysical land-surface data set from NOAA AVHRR data. J Hydrometeor 1: 183-199.

MATthews E. 1983. Global vegetation and land use: new high-resolution data bases for climate studies. J Clim Appl Meteorol 22: 474-487 (map available at: http://www.giss.nasa.gov/data/landuse/vegeem.html).

Monserud RA AND LeEMANS R. 1992. Comparing global vegetation maps with the Kappa statistic. Ecol Model 62: 275-293.

ODUM EP. 1983. Basic Ecology, New York: CBS College Publishing, $434 \mathrm{p}$.
OLSON JS. 1994. Global ecosystem framework-definitions, USGS EROS Data Center Internal Report, Sioux Falls: US Geol Surv S D, 37 p.

OYAMA MD AND NOBRE CA. 2004. A simple potential vegetation model for coupling with the Simple Biosphere Model (SIB). Rev Bras Meteorol 19: 203-216.

RAMANKUTTY N AND FOLEY JA. 1999. Estimating historical changes in global land cover: croplands from 1700 to 1992. Global Biogeochem Cy 13: 997-1027 (map available at: http://islscp2.sesda.com/ISLSCP2_1/html_pages/ islscp2_home.html).

SAlazAr LF, Nobre CA AND Oyama MD. 2007. Climate change consequences on the biome distribution in tropical South America. Geophys Res Lett 34 L09708 doi:10.1029/2007GL029695.

SChultz J. 2005. The ecozones of the world: the ecological divisions of the geosphere, 2nd ed., Berlim: SpringerVerlag, $252 \mathrm{p}$.

Sellers PJ, Mintz Y, Sud YC And Dalcher A. 1986. A Simple Biosphere Model ( $\mathrm{SiB}$ ) for use within General Circulation Models. J Atmos Sci 43: 505-531.

Sellers PJ, Los SO, Tucker CJ, Justice CO, Dazlich DA, Collatz GJ and Randall DA. 1996. A revised land surface parameterization (SiB2) for Atmospheric GCMs. Part II: the generation of global fields of terrestrial biophysical parameters from satellite data. J Climate 9: 706-737.

UNESCO. 1988. The UNESCO classification of vegetation. In: KÜCHLER AW AND ZONNEVELd IS (Eds), Vegetation Mapping, Dordrecht: Kluwer Academic Publishers, 1988, p. 531-549.

Vourlitis GL, Priante Filho N, Hayashi MMS, Nogueira JS, CASEIRo FT AND CAMPelo JR JH. 2001. Seasonal variations in the net ecosystem $\mathrm{CO}_{2}$ exchange of a mature Amazonian transitional tropical forest (cerradão). Funct Ecol 15: 388-395.

Xue Y, Sellers PJ, Kinter JL and Shukla J. 1991. A Simplified Biosphere Model for Global Climate Studies. J Climate 4: 345-364.

Wright IR, Nobre CA, TOMAsella J, Rocha HR, Roberts JM, Vertamatti E, Culf AD, Alvalá RCS, HodnetT MG AND UbARANA V. 1996. Towards a GCM surface parameterization of Amazonia. In: GASH JHC, Nobre CA, Roberts JM AND Victoria RL (Eds), Amazonian Deforestation and Climate, Chichester: J Wiley \& Sons, p. 473-504. 